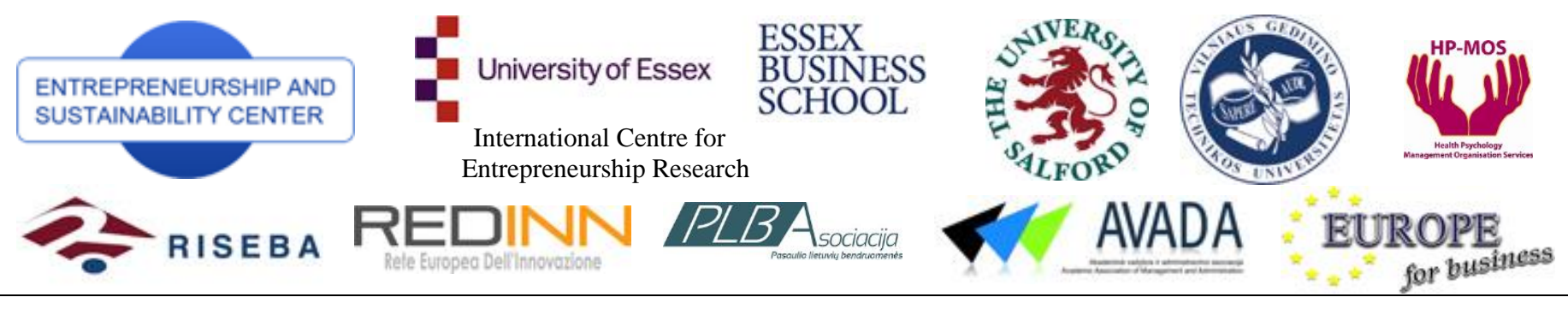

ENTREPRENEURSHIP AND SUSTAINABILITY ISSUES

ISSN 2345-0282 (online) http://jssidoi.org/jesi/

\title{
HOUSEHOLD INCOME AND SATISFACTION WITH LIFE: COGNITIVE - EMOTIONAL IMPACT PARADOX ${ }^{1}$
}

\author{
Aiste Dirzyte் ${ }^{1}$, Ona Gražina Rakauskiené2 Vaida Servetkiené $^{3}$ \\ 1,2,3 Mykolas Romeris University, Ateities str. 20, LT 08303 Vilnius, Lithuania \\ E-mails: aiste.dirzyte@gmail.com; ona.rakaus@gmail.com; vaida@mruni.eu
}

Received 20 July, 2016; accepted 25 September 2016

\begin{abstract}
Much of the discussion over satisfaction with life has focused on the significance of income. Some researchers argue that cognitive factors (expectations, social comparisons, life evaluations, schemas) is the mediating part between income and subjective wellbeing, however, positive psychology suggests that happiness determines the effect of social comparison itself. This paradox could be titled "cognitive - emotional impact paradox". We have chosen to explore this paradox and investigate the relationship between household income, cognitions, emotions, and satisfaction with life in Lithuania, as various studies, including "World Value Survey", indicate Lithuania is among the countries demonstrating very low scores on happiness of population even though its' economy grew fast when this country regained its' independence in 1991. This paper presents some results of the survey which was conducted in 2016 (representative sample, $\mathrm{n}=1001$ ). The analysis of data has demonstrated that when people get low household income per month, they report more intense negative emotions and less positive emotions. Secondly, our results suggest that people getting low household income per month express more negative cognitions and less positive cognitions. Thirdly, the results demonstrated strong relationship between cognitions, emotions, and satisfaction with life. Moreover, the results contribute to the empirical literature on "income - happiness" relation by demonstrating that household income has no significant direct effect on satisfaction with life, but there is a significant effect of household income on basic cognitions, which have a significant effect on emotions. Subsequently, basic cognitions and emotions have an effect on satisfaction with life. However, "cognitive - emotional impact paradox" needs further exploration.

This research is funded by the Research Council of Lithuania (No. GER-009/2015).
\end{abstract}

Keywords: household income, subjective wellbeing, happiness, Lithuania

Reference to this paper should be made as follows: Dirzytė, A.; Rakauskiené, O.G.: Servetkiené, V. 2016. Household income and satisfaction with life: cognitive - emotional impact paradox, Entrepreneurship and Sustainability Issues 4(2): 198-210. DOI: http://dx.doi.org/10.9770/jesi.2016.4.2(7)

JEL Classifications: D63; A14; I31; R20

${ }^{1}$ This work was supported by the Research Council of Lithuania [grant number GER-009/2015]. 


\section{Introduction}

In cognitive therapy, which is the most widely applied intervention to enhance subjective wellbeing, there is a central premise that cognitions (thoughts, beliefs, personal constructs, cognitive schemas, expectations) give rise to emotions (Beck, 2014). In other words, emotions are consequence of certain cognitions. Negative cognitions like "life is meaningless" might result in emotions like sadness and despair, while positive cognitions like "we are created like this" (Yalom, 1989) might result in emotional relief, peacefulness and even happiness.

Currently, researchers have been envisaging emotions as constituent of wellbeing. In methodological recommendations of assessing psychological wellbeing, it is suggested to evaluate person's positive and negative emotions (emotional component), and not just focus on satisfaction with life (cognitive component).

Moreover, it is supposed that happiness as emotion might contribute to various behavioral and health consequences. For example, it was found that happiness promotes multiple successful life outcomes, including superior health, higher income, stronger relationships (Lyubomirsky, King \& Diener, 2005).

Recent research shows differences in cognitions of happy and unhappy people: happy and unhappy individuals differ considerably in their subjective experience and construal of the world (Lyubomirsky, 2001). Besides, happy people have been found to use a positive perspective when evaluating themselves and others (Lyubomirsky \& Tucker, 1998); they also tend to judge almost everything about themselves and their lives favorably, including their friendships, recreation, self-esteem, energy levels, and purpose in life (Lyubomirsky, Tkach, et al., 2006).

Furthermore, research has also showed that the self-perceptions of happy individuals are relatively invulnerable to social comparisons (Boehm \& Lyubomirsky, 2009), happy people's emotions and self-regard are much less impacted by comparisons with others than those of unhappy persons (Boehm \& Lyubomirsky, 2009), unhappy people are more responsive to both group and individual information, particularly in "failure" situations (Boehm \& Lyubomirsky, 2009), unhappy people engage in negative and maladaptive dwelling more so than do happy people, and their excessive dwelling not only makes them feel bad, but brings about significant detrimental outcomes (Lyubomirsky \& Kasri, 2006), happy people are relatively more likely to report endowing past positive life experiences and contrasting negative life experiences (i.e., considering how much better off they are today), whereas unhappy people are relatively more likely to report ruminating about negative experiences and contrasting positive experiences (i.e., considering how much worse off they are today) (Liberman et al., 2008).

Moreover, emotions were found to be related to satisfaction or dissatisfaction with different aspects of life: happy people tend to be more satisfied with all of their available options (including the option they eventually choose) and only express dissatisfaction in situations when their sense of self is threatened (Boehm \& Lyubomirsky, 2009). In one interesting study people were asked to rate the attractiveness of several desserts, and they increased their liking for the dessert they got and didn't change their liking for the dessert they couldn't get, while unhappy people found the option they were given to be minimally acceptable (derogating that dessert after learning they could keep it) (Lyubomirsky \& Ross, 1999). In another study, after being accepted by individual colleges, happy people boosted their liking and judgments of those colleges (Lyubomirsky et al., 2005). These findings suggest that "happy people's strategies of processing life events serve to prolong and preserve positive emotions, whereas the strategies of unhappy individuals serve to dampen the inherent positivity associated with positive events and to enhance the negative affect associated with negative events" (Boehm \& Lyubomirsky, 2009).

How these positive psychology findings might be applied to economic psychology? The well-known scholar of economic psychology R. A. Easterlin, who has created the famous "Easterlin income-happiness paradox" (2001) argued that more income should bring greater happiness; nevertheless, aspirations grow along with income. In other words, money does not bring happiness as certain expectations prevent that. This conclusion is absolutely 


\section{The International Journal \\ ENTREPRENEURSHIP AND SUSTAINABILITY ISSUES}

ISSN 2345-0282 (online) http://jssidoi.org/jesi/ 2016 Volume 4 Number 2 (December)

true from the point of cognitive therapy. However, if we keep the notion that merely cognitions (expectations) explain whether a person is happier or not, then what is the meaning of economic psychology? Wouldn't it be better to explore the cognitive profile of a happy person in all income groups, and then let cognitive therapists do their work to increase happiness of societies?

Some research suggests it wouldn't be better: income still matters for happiness. For example, Ball, R., \& Chernova, K. (2008) used data from the World Values Survey to investigate how an individual's self-reported happiness is related to the level of income in absolute terms, and the level of income relative to other people in the country. They found that "both absolute and relative incomes are positively and significantly correlated with happiness, quantitatively, changes in relative income have much larger effects on happiness than do changes in absolute income, and the effects on happiness of both absolute and relative income are small when compared to the effects several non-economic factors" (Ball, Chernova, 2008).

Nonetheless, some researchers still refer to the importance of cognitive factors in income-happiness relationship. Greve, B. (2012) reasoned that, "in general, countries with a higher income per capita have higher levels of happiness; nevertheless, as Easterlin has observed, an increase in income is not necessarily correlated with an increase in happiness. Based upon recent data from the European Social Survey, Greve has tried to fill this gap by looking at changes in happiness in the wake of the recent financial crisis and consequent change in income as measured by gross domestic product per capita. However, the data for 15 European countries suggested that such a causal relationship cannot be confirmed on the basis of the present limited data" (Greve, 2012). Likewise, Becchetti, L., Corrado, L., \& Rossetti, F. (2011) argued that "the standard money-happiness relationship provides a partial and incomplete picture of the complex connection between happiness and income as it does not take into account the role of peers and of reference group income and that of the dynamics between realizations and expectations" (Becchetti, Corrado, \& Rossetti, 2011).

Many researchers refer to the importance of social comparison in income- happiness relationships (but already from the findings of Lyubomirsky we know that it matters just for unhappy people). Guven, C., \& Sørensen, B. (2012) found that "reference group income negatively relates to own happiness and high perceptions about own relative income, quality of dwelling and social class relate positively and very significantly to happiness. Perceptions about income and status are more significant for females, and for low income, conservative, more social, and less trusting individuals. Dwelling perceptions matter more for males, and for middle income, married, conservative, more social, and less trusting individuals" (Guven \& Sørensen, 2012).

Interestingly, Clark, A. E., Frijters, P., \& Shields, M. A. (2008) reasoned that income may be evaluated in relation to others (social comparison) or to oneself in the past (habituation). They reviewed the evidence on relative income from the subjective well-being literature, and concluded that "taking relative income seriously is an important step toward greater behavioral realism in Economics, such that models and empirical analysis move closer to how real people feel and behave. They concluded that utility functions including relative income terms produce a wide variety of testable predictions regarding both well-being (measured by survey or neurologically) and observable behaviors: it is not true that "anything goes." Clark, Frijters, \& Shields argue "there is need to appeal to both direct measures of utility and observed behavior in order to obtain a better idea of what the utility function looks like, and make policy recommendations in the best interest of society" (Clark, Frijters, Shields, 2008). Remarkably, Gundlach, E., \& Opfinger, M. (2013) analyzed some applications of basic utility theory. Researchers found a positive correlation between happiness and religiosity, a positive correlation between happiness and income, and a negative correlation between religiosity and income (Gundlach, Opfinger, 2013).

What are the results of the other recent studies on income-happiness relationship and the related factors? They are multiple and multivariate. Bruni L., \& Stanca L. (2006) offered an alternative explanation of Easterlin's income happiness paradox: "television viewing in contemporary society, by raising material aspirations, contributes to offset the effect of higher income on individual happiness" (Bruni \& Stanca, 2006, p. 225). 
However, Schneider, L. (2013) has demonstrated that there is no significant, positive and robust impact of TV consumption on material aspirations, even though this hypothesis cannot be totally disapproved, and suggested applying a more direct approach of measuring the effect of TV on material aspirations (Schneider, 2013). Budria, S. (2013) claimed that relative income effects cannot be regarded as constant across the subjective wellbeing distribution, and that the results are consistent with previous findings as they show that happy individuals are particularly successful at defending themselves against the potentially negative hedonic consequences of unfavorable comparisons and in using social comparison information strategically to increase their subjective wellbeing, while unhappy individuals tend to interpret unfavorable social comparison information more pessimistically or to focus on their negative aspects (Budria, 2013).

Cullis, J., Hudson, J., \& Jones, P. (2011) confirmed the importance for happiness of relative income, average standard of living, marital status and age (Cullis, Hudson, \& Jones, 2011). Fischer, C. S. (2008) revealed a modest but real correlation between material well-being and national happiness (Fischer, 2008). Gleibs, I. H., Morton, T. A., Rabinovich, A., Haslam, S. A., \& Helliwell, J. F. (2013) showed that both money (individual income) and community (social capital) can be the basis for individual happiness, however, the relative influence of each factor depends on the context within which happiness is considered, and how this shapes the way people define the self (Gleibs et al., 2013). Headey, B., Muffels, R., \& Wooden, M. (2008) found that happiness is considerably more affected by economic circumstances than previously believed: wealth affects life satisfaction more than income (Headey, Muffels \& Wooden, 2008). Powdthavee, N. (2010) suggested money buys little happiness, and a reevaluation on how the calculation of compensatory packages to various shocks in the individual's life events should be designed (Powdthavee, 2010). Roszkowski, M. J., \& Grable, J. (2007) demonstrated surprisingly weak correlation between money and happiness: they found that net worth is a stronger correlate of satisfaction with one's financial situation than is household income, but they could not demonstrate that net worth is also more strongly associated with happiness with life in general (Roszkowski, \& Grable, 2007). Zuzanek, J. (2013) found that higher household income correlate positively with respondents' retrospective assessments of life satisfaction, but economic growth has not been accompanied by a corresponding rise of subjective wellbeing (Zuzanek, 2013).

Zhang, H., \& Tsang, S. (2013) found that "a woman married to a husband with lower income tended to be less happy with her marriage, but hopefully, this effect could be countered if there is more love in the sense of a genuine concern about the well-being of the partner and a willing to make sacrifice for him" (Zhang \& Tsang, 2013). Some findings look questionable: Kuroki, M. (2013) has even concluded that "happiness of the wealthy, which can afford to lose some money as well as buy some safety, is not affected by the direct experience of burglary or robbery"! (Kuroki, 2013). This conclusion could be highly doubted from the perspective of trauma psychology.

To sum up, there is a variety of studies which suggests that this field needs additional exploration, as there are lots of contradictions and paradoxes. It could be concluded that cognitive factors (expectations, social comparisons, life evaluations, schemas) is the mediating part between income and happiness, however, positive psychology suggests that happiness determines the effect of social comparison itself! This paradox could be named "cognitive - emotional impact paradox". Even though cognitive therapy model clearly points out to the primary role of cognitions, positive psychology model refers to the possible primary role of some emotional factors.

In this paper we empirically examine how household income relates to emotions, cognitions, and satisfaction with life. Various studies, including "World Value Survey", indicate that for decades Lithuania has been among the countries demonstrating the lowest scores on happiness and the highest rates of suicides in Europe. However, according to the GDP data, Lithuania is not among the poorest countries of the world. On the contrary, Lithuanian governments have claimed that the States' economic situation has been progressing considerably since Lithuania regained its' independence in 1991. As Lithuanians still are not happier, and some of them (especially, low 
income groups) even create a lot of problems in society and other countries, this sample is particularly interesting and relevant to explore. Therefore, we aimed at evaluating the cognitive - emotional processes underlying "happiness - income relation": association between emotions, cognitions, satisfaction with life, and household net income.

We make the following new contributions. Firstly, we find that when people get low household income per month, they report more intense negative emotions, and demonstrate less positive emotional states. Secondly, our results suggest that people getting low household income per month express more negative cognitions and report less positive cognitions. Thirdly, the results demonstrated strong relationship between positive cognitions, positive emotions, and satisfaction with life. Our results contribute to the empirical literature on "income happiness" relationship by demonstrating that household income has no significant direct effect on satisfaction with life, but there is a significant effect of household income on cognitions and emotions which, subsequently, have an effect on satisfaction with life.

\subsection{Survey and sample characteristics}

This study used a test design utilizing a heterogeneous random sample of 1001 person representing Lithuanian population. All the participants were personally asked to participate in the study. Lithuanian respondents were personally interviewed at their home, the interview took approximately 1,5 hours. Lithuanian sample was selected in a multi-scaled probabilistic way so that every citizen of Lithuania might have an equal probability to be interviewed. The survey was performed in 2016. K- means analysis was applied to cluster the respondents into low, medium and high household net income groups.

\subsection{Measures}

The measures used in this study included:

The Satisfaction with Life Scale or SWLS was used to assess psychological wellbeing. This measure was developed by Ed Diener (Diener, Emmons, et al., 1985), and it involves five questions, rated on a Likert-type scale including response options ranging from "totally disagree" to "totally agree". The SWLS has been validated in many contexts (Diener, 2004). The Satisfaction with Life Scale demonstrated acceptable reliability in this study: SWLS Cronbach's alpha for Lithuanian sample was $=.89$.

Emotional states scale. To assess specific states of Lithuanian population, we have created a modified version of the Positive and Negative Affect Scale, created by Watson, 1994 and SPANE, created by Ed Diener and Robert Biswas-Diener, 2009. All responses were anchored on a 6-point Likert scale, ranging from "never" to "always". Cronbach's alpha for this sample was $=.82$.

Basic cognitions scale. To assess Lithuanians' attitudes towards life, we have created a questionnaire based on the works of positive psychology scholars (e.g., Diener \& Seligman, 2004; Warburton, 1996; Veenhoven, 2003; Ryan \& Deci, 2000; Tov \& Diener, 2009; Sirgy \& Wu, 2009; Sirgy, 2012; Seligman, 2011; Ryff \& Singer, 1996; Parducci, 1995; Hayborn, 2008; Diener, Wirtz, Tov, Kim-Prieto, Choi, Oishi \& Biswas-Diener, 2010). It involves questions, rated on a Likert-type scale including 6 - point response options ranging from "totally disagree" to "totally agree". The self-reported measure of basic cognitions is constructed from the following questionnaires: Flourishing scale, Ed Diener and Robert Biswas-Diener, 2009; Hadley Cantril's Self-Anchoring Striving Scale, 1965; PSYCAP, F. Luthans, 2007. All the listed questionnaires, presented in this study, demonstrated acceptable reliability: Cronbach's alpha for this sample varied from .80 to $.92(n=1001)$. 
Survey was held in: Vilnius, Kaunas, Klaipèda, Šiauliai, Panevėžys, Alytus District, Šakiai District, Utena District, Tauragė District, Švenčionys District, Raseiniai District, Kupiškis District, Molètai District, Akmenė District, Rokiškis District, Telšiai District, Mažeikiai District, Marijampole District, Trakai District, Varẻna District, Kretinga District and Ukmerge District. The research was conducted in 19 cities and 24 villages.

\section{Results}

\subsection{Effect of household income on self-reported emotional states}

A one-way between subjects ANOVA was conducted to compare the effect of household income per month on emotional states during the last week in clustered low, average, and high household income conditions.

There was a significant effect of household income per month on negative emotional states at the $\mathrm{p}<.05$ level for the following emotions: anger $\mathrm{F}(2,906)=3.10, \mathrm{p}=.045, \eta \mathrm{p} 2=.007$, despair $\mathrm{F}(2,903)=8.26, \mathrm{p}=.000, \eta \mathrm{p} 2=$ .018 , fear $\mathrm{F}(2,902)=5.51, \mathrm{p}=.004, \eta \mathrm{p} 2=.012$, sadness $\mathrm{F}(2,904)=5.06, \mathrm{p}=.007, \eta \mathrm{p} 2=.011$.

However, there was not a significant effect of household income per month on emotional states at the $\mathrm{p}<.05$ level for the following emotions: anxiety $\mathrm{F}(2,906)=1.56, \mathrm{p}=.210$, shame $\mathrm{F}(2,895)=0.10, \mathrm{p}=.904$, guilt $\mathrm{F}(2,903)=$ $2.63, \mathrm{p}=.528$.

Posthoc analyses using Tukey's HSD indicated that the mean anger score was significantly higher for medium household income group to compare with low income group ( $\mathrm{p}=.036)$, but significantly lower to compare with highest income group which demonstrated the highest anger scores $(\mathrm{p}=.041)$.

Sadness was significantly higher for low household income group to compare with medium income group $(\mathrm{p}=.004)$, but the highest income group did not differ significantly between participants with low or medium income.

Interestingly, there was a significant effect of household income per month on positive emotional states at the $\mathrm{p}<.05$ level for the following emotions: peace $\mathrm{F}(2,897)=6.64, \mathrm{p}=.001, \eta \mathrm{p} 2=.015$., happiness $\mathrm{F}(2,896)=8.39$, $\mathrm{p}=.000, \eta \mathrm{p} 2=.018$., optimism $\mathrm{F}(2,897)=8.87, \mathrm{p}=.000, \eta \mathrm{p} 2=.019$., hopefulness $\mathrm{F}(2,896)=8.29, \mathrm{p}=.000$, $\eta \mathrm{p} 2=.018$, joy $\mathrm{F}(2,897)=6.23, \mathrm{p}=.002, \eta \mathrm{p} 2=.013$.

Post hoc comparisons using the Tukey HSD test indicated that the mean score of above listed positive emotions was significantly different for the low, medium and high household income groups: the mean peace score was significantly higher for the high household income group to compare with low income group $(\mathrm{p}=.004)$ or medium household income group $(\mathrm{p}=.039)$.

Happiness mean score was significantly lower for low household income group to compare with medium household income group ( $\mathrm{p}=.002)$ or high household income group ( $\mathrm{p}=.033)$. However, the medium and high household income groups did not differ significantly.

Optimism was significantly lower $(\mathrm{p}=.001)$ for the low income group to compare with medium income group, but the high income group did not differ significantly between participants with low and medium income. Compassion was significantly higher for the high household income group to compare with low income group $(\mathrm{p}=.031)$, but it did not differ significantly to compare with medium income group. 
Hopefulness was significantly higher for medium household income group to compare with low income group $(\mathrm{p}=.001)$, but the high income group did not differ significantly between participants with low and medium income.

The mean score of joy was significantly lower for low income group ( $\mathrm{p}=.012)$, but the high household income group did not differ significantly between participants with low and medium income.

Taken together, these results suggest that household income per month really do have an effect on emotional states. Specifically, our results suggest that when people get low household income per month, they report more intense negative emotions, and demonstrate less positive emotional states. However, it should be noted that household income differences level must be high in order to see an effect. High household income appears to significantly increase positive emotions and diminish negative emotions to compare with low household income group, and medium household income appears to significantly increase positive emotions and diminish negative emotions to compare with low household income group, but mostly high household income does not appear to significantly increase positive emotions and diminish negative emotions in compare to medium household income group.

\subsection{Effect of household income on cognitions}

A one-way between subjects ANOVA was conducted to compare the effect of household income per month on cognitions (perceptions of self and life) in low, average, and high household income conditions.

There was a significant effect of household income per month on perceptions of self and life at the $\mathrm{p}<.05$ level for the following positive cognitions: "I have clear life goals" $F(2,903)=21.50, p=.000, \eta p 2=.045$, "I think I am a happy person" $\mathrm{F}(2,905)=19.89, \mathrm{p}=.000, \eta \mathrm{p} 2=.042$, "There are a lot of people with whom ever I can openly talk about my concerns" $F(2,904)=3.21, \mathrm{p}=.041, \eta \mathrm{p} 2=.007$, "I am satisfied with my life" $\mathrm{F}(2,909)=26.30, \mathrm{p}$ $=.000, \eta \mathrm{p} 2=.055$, "My life is valuable" $\mathrm{F}(2,908)=19.98, \mathrm{p}=.000, \eta \mathrm{p} 2=.042$, "I trust in myself, that I will successfully overcome the difficulties / challenges of life" $F(2,909)=15.40, p=.000, \eta p 2=.032$.

Posthoc analyses using Tukey's HSD indicated that in low income group were significantly weaker expressed all positive cognitions. Significantly weaker was expressed cognition "I have clear life goals" to compare with medium ( $\mathrm{p}=.000)$ and high $(\mathrm{p}=.001)$ household income groups, cognition "I think I am a happy person", to compare with medium ( $\mathrm{p}=.000)$ and high $(\mathrm{p}=.001)$ household income groups, cognition "There are a lot of people with whom ever I can openly talk about my concerns" to compare with medium $(p=.000)$ and high $(p=.001)$ household income groups, cognition "I am satisfied with my life" to compare with medium ( $\mathrm{p}=.000)$ and high $(\mathrm{p}=.001)$ household income groups, cognition "My life is valuable" to compare with medium ( $\mathrm{p}=.000)$ and high $(\mathrm{p}=.001)$ household income groups, cognition "I trust in myself, that I will successfully overcome the difficulties / challenges of life" to compare with medium $(\mathrm{p}=.000)$ and high $(\mathrm{p}=.001)$ household income groups.

Taken together, these results suggest that household net income per month really do have an effect on cognitions. Specifically, our results suggest that people getting low household income per month, express more negative cognitions and less positive cognitions.

\subsection{Satisfaction with life in high, medium and low household income groups in positive and negative emotional clusters}

A 2 X 2 factorial analysis of variance tested the effects of the household income and emotions on respondent's satisfaction with life. Results has indicated a significant main effect for the emotions factor, $F(1,886)=27.01, p=$ 
$.000, \eta \mathrm{p} 2=.03$. As hypothesized, those who reported more positive emotions showed higher satisfaction with life $(\mathrm{M}=3.71, \mathrm{SD}=.88)$ compared to those who reported more negative emotions $(\mathrm{M}=2.87, \mathrm{SD}=.96)$.

Results has also indicated a significant main effect for the income factor, $F(2,886)=6.09, p=.002, \eta p 2=.014$. People in the low income group were the least satisfied with life $(\mathrm{M}=3.40, \mathrm{SD}=.98)$ compared to medium income group $(\mathrm{M}=3.76, \mathrm{SD}=.90)$ or high income group $(\mathrm{M}=4.12, \mathrm{SD}=.85)$. Posthoc analysis using Bonferroni indicated that mean difference in satisfaction with life was significant for low and medium income group ( $\mathrm{p}<.001)$, as well as low and high income group $(\mathrm{p}=.001)$, however, as demonstrated in Table 1 , the mean difference was not significant for medium and high income groups $(\mathrm{p}=.270)$.

Table 1.

Satisfaction with Life Means for Different Household Income and Emotions Groups.

\begin{tabular}{|c|c|c|c|c|c|}
\hline Household income groups, per month & Emotions clusters & M & SE & \multicolumn{2}{|c|}{$95 \% \mathrm{CI}$} \\
\hline \multirow[t]{2}{*}{ Low } & Negative emotions & 2.82 & .063 & {$[2.70$} & 2.94] \\
\hline & Positive emotions & 3.62 & .040 & {$[3.54$,} & 3.70] \\
\hline \multirow[t]{2}{*}{ Medium } & Negative emotions & 3.16 & .146 & {$[2.88$,} & $3.45]$ \\
\hline & Positive emotions & 3.91 & .073 & {$[3.76$,} & 4.05] \\
\hline \multirow[t]{2}{*}{ High } & Negative emotions & 2.30 & .629 & {$[1.06$,} & 3.53] \\
\hline & Positive emotions & 4.32 & .210 & {$[3.91$,} & 4.73] \\
\hline
\end{tabular}

Note. $\mathrm{M}=$ mean, $\mathrm{SE}=$ Standard Error, $\mathrm{CI}=$ confidence interval.

A 2 X 2 factorial analysis of variance tested the effects of the household income and cognitions on respondent's satisfaction with life. Results has indicated a significant main effect for the cognitions factor, $F(1,870)=18.74, p$ $=.000, \eta \mathrm{p} 2=.021$. As demonstrated in Table 2 , those who reported more positive cognitions, showed higher satisfaction with life $(\mathrm{M}=4.11, \mathrm{SD}=.77)$ compared to those who reported more negative cognitions $(\mathrm{M}=3.07$, $\mathrm{SD}=.92$ ).

\section{Table 2.}

Satisfaction with Life Means for Different Household Income and Cognitions Groups.

\begin{tabular}{|c|c|c|c|c|c|}
\hline Household income groups, per month & Cognitions clusters & M & SE & \multicolumn{2}{|c|}{$95 \% \mathrm{CI}$} \\
\hline \multirow[t]{2}{*}{ Low } & Negative cognitions & 3.05 & .041 & {$[2.97$} & 3.13] \\
\hline & Positive cognitions & 4.07 & .058 & {$[3.96$, } & 4.18] \\
\hline \multirow[t]{2}{*}{ Medium } & Negative cognitions & 3.13 & .103 & {$[2.92$,} & 3.33] \\
\hline & Positive cognitions & 4.19 & .082 & {$[4.03$,} & 4.35] \\
\hline \multirow[t]{2}{*}{ High } & Negative cognitions & 3.80 & .502 & {$[2.81$,} & 4.78] \\
\hline & Positive cognitions & 4.17 & .217 & {$[3.75$,} & 4.60] \\
\hline
\end{tabular}

Note. $\mathrm{M}=$ mean, $\mathrm{SE}=$ Standard Error, $\mathrm{CI}=$ confidence interval.

Furthermore, bivariate correlation of positive cognitions, positive emotions and satisfaction with life revealed strong significant $(\mathrm{p}<0.001)$ positive relationships between the factors, as demonstrated in Table 3. 
Table 3.

Bivariate Correlations of Positive Cognitions, Positive Emotions, and Satisfaction with Life.

\begin{tabular}{ccccc}
\hline & $M$ & $S D$ & Positive cognitions & Positive emotions \\
\hline 1. Positive cognitions & 4.05 & $(.79)$ & 1 & 1 \\
2. Positive emotions & 3.82 & $(1.32)$ & $.530^{* *}$ & $.500^{* *}$ \\
3. Satisfaction with life & 3.52 & $(1.05)$ & $.657^{* *}$ & **. Correlation is significant at the 0.01 level (2-tailed).
\end{tabular}

Structural equation modeling (SEM) using software package AMOS has been applied to investigate theoryderived structural hypotheses. The results are demonstrated in Table 4 and Figure 1.

Table 4.

Unstandardized, Standardized, and Significance Levels for Model in Figure 1 (Standard Errors in Parentheses) Parameter Estimate Unstandardized Standardized $p$

Total household net income $\rightarrow$ Cognitions Cognitions $\rightarrow$ Emotions

Emotions $\rightarrow$ Satisfaction with life Cognitions $\rightarrow$ Satisfaction with life Total household net income $\rightarrow$ Satisfaction with Life

\begin{tabular}{lll}
$.00(.00)$ & .26 & .00 \\
$.90(.05)$ & .55 & .00 \\
$.15(.02)$ & .19 & .00 \\
$.74(.04)$ & .56 & .00 \\
$.00(.00)$ & .03 & .25 \\
\hline
\end{tabular}

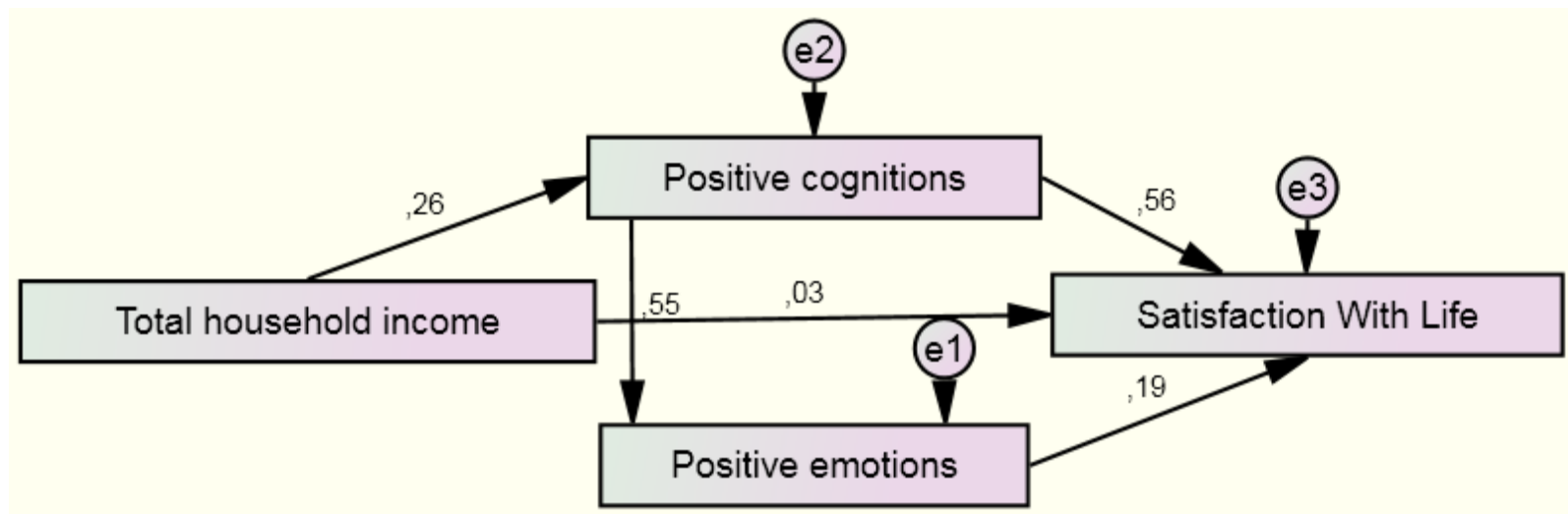

Figure 1.

Structural Equation Model of Interactions between Total Household Net Income, Positive Cognitions, Positive Emotions, and Satisfaction with Life (Standardized Solution).

Taken together, the results mean that household net income has no significant direct effect on satisfaction with life $(\beta=.029 ; \mathrm{p}=.246), \mathrm{R}^{2}=.454, \chi^{2}(1, n=916)=0.16, \mathrm{p}=.690, \mathrm{RMSEA}=.000 ; \mathrm{CMIN} / \mathrm{DF}=.159, \mathrm{RFI}=.998$. However, there is a significant effect of household net income on cognitions $(\beta=.262 ; \mathrm{p}<0.001)$, and, subsequently, there is a significant strong effect of cognitions on emotions $(\beta=.548 ; \mathrm{p}<0.001)$. Moreover, there is a significant effect of cognitions $(\beta=.564 ; \mathrm{p}<0.001)$ and emotions $(\beta=.189 ; \mathrm{p}<0.001)$ on satisfaction with life. 


\section{Conclusions}

The presented study aimed at evaluating the effect of household income on cognitions, emotions and satisfaction with life in Lithuanian representative sample. There was found a significant effect of household income per month on several negative emotional states.

Interestingly, there was a significant effect of household income per month on positive emotional states for the following emotions: peace, happiness, optimism, hopefulness, joy. Taken together, these results suggest that household income per month really do have an effect on emotional states during the last week. Specifically, our results suggest that when people get low household income per month, they report more intense negative emotions, and demonstrate less positive emotional states.

However, it should be noted that household income differences level must be high in order to see an effect. High household income appears to significantly increase positive emotions and diminish negative emotions to compare with low household income group, and medium household income appears to significantly increase positive emotions and diminish negative emotions to compare with low household income group, but mostly high household income does not appear to significantly increase positive emotions and diminish negative emotions in compare to medium household income group.

The results have also demonstrated a significant effect of household income per month on perceptions of self and life for the negative cognitions. These cognitions were more expressed in low household income group. Moreover, there was a significant effect of household income per month on perceptions of self and life for some positive cognitions. These results suggest that household income per month really do have an effect on cognitions. Specifically, our results suggest that when people get low household income per month, they express more negative cognitions and less positive cognitions.

The analysis of effects of the household income and emotions on respondent's satisfaction with life has indicated a significant main effect for the emotions factor. Those who reported more positive emotions showed higher satisfaction with life compared to those who reported more negative emotions. Results have also indicated a significant main effect for the income factor. The mean difference in satisfaction with life was significant for low and medium income group, as well as low and high income group, however, the mean difference was not significant for medium and high income groups.

The analysis of effects of the household income and cognitions on respondent's satisfaction with life has indicated a significant main effect for the cognitions factor: those who reported more positive cognitions, showed higher satisfaction with life compared to those who reported more negative cognitions.

Bivariate correlation revealed strong significant positive relationships between positive cognitions, positive emotions and satisfaction with life.

Our results contribute to the empirical literature on "income - happiness" relationship (Easterlin, 2001; Diener, 2004; Graham, 2010). The results support model of R. A. Easterlin on the importance of cognitions in "moneyhappiness" association. Moreover, it supports works of E. Diener on the higher impact of money on happiness in poorer societies.

Structural equation modeling (SEM) demonstrated that household net income has no significant direct effect on satisfaction with life, but there is a significant effect of household income on cognitions, and a significant effect of cognitions on emotions. Subsequently, cognitions and emotions have an effect on satisfaction with life. Therefore, our results contribute to the theoretical discussion on household income and satisfaction with life role 
in A (activating factor) - B (beliefs) - C (consequences) model. Low household income activates Lithuanian's negative cognitions, life and self- perceptions, which might give rise to negative emotional states, inability to feel peacefulness, happiness, and these factors altogether lower Lithuanians' satisfaction with life. Nevertheless, the present study still cannot explain "cognitive - emotional impact paradox". The results affirm the role of cognitive factors; however, some authors (e.g., Diener, 2010) would argue that satisfaction with life itself is a cognitive component of subjective wellbeing. The core of "cognitive - emotional impact paradox" is that cognitive factors (expectations, social comparisons, life evaluations, schemas) is the mediating part between income and happiness, however, positive psychology suggests that happiness determines the effect of social comparison itself. Cognitive therapy model would point out to the primary role of cognitions in "money-happiness" relationship, but positive psychology refers to the possible primary role of emotional factors, and this paradox needs further exploration.

\section{References}

Antonides, G. (2007). Income Evaluation and Happiness in the Case of an Income Decline. Kyklos, 60(4), 467-484. doi:10.1111/j.14676435.2007.00381.x

Ball, R., \& Chernova, K. (2008). Absolute Income, Relative Income, and Happiness. Social Indicators Research, 88(3), 497-529. doi:10.1007/s11205-007-9217-0

Bartolini, S., Bilancini, E., \& Pugno, M. (2013). Did the Decline in Social Connections Depress Americans' Happiness? Social Indicators Research, 110(3), 1033-1059. doi:10.1007/s11205-011-9971-x

Bartram, D. (2011). Economic Migration and Happiness: Comparing Immigrants' and Natives' Happiness Gains From Income. Social Indicators Research, 103(1), 57-76. doi:10.1007/s11205-010-9696-2

Becchetti, L., Corrado, L., \& Rossetti, F. (2011). The Heterogeneous Effects of Income Changes on Happiness. Social Indicators Research, 104(3), 387-406. doi:10.1007/s11205-010-9750-0

Becchetti, L., Trovato, G., \& Bedoya, D. L. (2011). Income, relational goods and happiness. Applied Economics, 43(3), 273-290. doi:10.1080/00036840802570439

Beck, AT (2014). Advances in Cognitive Theory and Therapy. Annual Review of Clinical Psychology, 10:1-24.

Boehm, J. K., \& Lyubomirsky, S. (2009). The Promise of Sustainable Happiness. In S. J. Lopez (Ed.), Handbook of Positive Psychology $\left(2^{\text {nd }}\right.$ ed.). Oxford: Oxford University Press.

Boes, S., \& Winkelmann, R. (2010). The Effect of Income on General Life Satisfaction and Dissatisfaction. Social Indicators Research, 95(1), 111-128. doi:10.1007/s11205-009-9452-7

Brockmann, H., Delhey, J., Welzel, C., \& Yuan, H. (2009). The China Puzzle: Falling Happiness in a Rising Economy. Journal of Happiness Studies, 10(4), 387-405. doi:10.1007/s10902-008-9095-4

Bruni, L., Stanca, L. (2006). Income Aspirations, Television and Happiness: Evidence from the World Values Survey. Kyklos, 59 (2), 209225.

Budria, S. (2013). Are Relative-Income Effects Constant Across the Well-Being Distribution?. Journal of Happiness Studies, 14(4), 13791408. doi:10.1007/s10902-012-9384-9

Carr, M. D. (2013). Local Area Inequality and Worker Well-Being. Review of Social Economy, 71(1), 44-64. doi:10.1080/00346764.2012.707399

Clark, A. E., Frijters, P., \& Shields, M. A. (2008). Relative Income, Happiness, and Utility: An Explanation for the Easterlin Paradox and Other Puzzles. Journal of Economic Literature, 46(1), 95-144. doi:10.1257/jel.46.1.95

Cullis, J., Hudson, J., \& Jones, P. (2011). A Different Rationale for Redistribution: Pursuit of Happiness in the European Union. Journal of Happiness Studies, 12(2), 323-341. doi:10.1007/s10902-010-9190-1

Diener, E., \& Seligman, M. E. P. (2004). Beyond Money: Toward an Economy of Well-being. Psychological Science in the Public Interest, 5, 1-31. Republished in E. Diener (Ed.). (2009). The Science of Well-being: The Collected Works of Ed Diener (pp. 201-265). Dordrecht, the Netherlands: Springer.

Diener, E., Emmons, R. A., Larsen, R. J., \& Griffin, S. (1985). The Satisfaction with Life Scale. Journal of Personality Assessment, 49, 71-75.

Diener, E., Wirtz, D., Tov, W., Kim-Prieto, C., Choi, D., Oishi, S., \& Biswas-Diener, R. (2010). New Well-being Measures: Short Scales to Assess Flourishing and Positive and Negative Feelings. Social Indicators Research, 97, 143-156.

Distante, R. (2013). Subjective Well-Being, Income and Relative Concerns in the UK. Social Indicators Research, 113(1), 81-105. doi:10.1007/s11205-012-0083-z

Dynan, K. E., \& Ravina, E. (2007). Increasing Income Inequality, External Habits, and Self-Reported Happiness. American Economic Review, 97(2), 226-231.

Easterlin, R. A. (2001). Income and Happiness: Towards a Unified Theory. Economic Journal, 111(473).

Ebert, U., \& Welsch, H. (2009). How do Europeans evaluate Income Distributions? An Assessment based on Happiness Surveys. Review of Income \& Wealth, 55(3), 803-819. doi:10.1111/j.1475-4991.2009.00347.x

Ellis, A., \& Blau, S. (2001). The Albert Ellis reader: A Guide to Well-being using Rational Emotive Behavior Therapy. New York: Citadel. 
Firebaugh, G., \& Schroeder, M. B. (2009). Does Your Neighbor's Income Affect Your Happiness? American Journal of Sociology, 115(3), 805-831.

Fischer, C. S. (2008). What Wealth - Happiness Paradox? A Short Note on the American Case. Journal of Happiness Studies, 9(2), 219226. doi:10.1007/s10902-007-9047-4

Gleibs, I. H., Morton, T. A., Rabinovich, A., Haslam, S. A., \& Helliwell, J. F. (2013). Unpacking the Hedonic Paradox: A Dynamic Analysis of the Relationships between Financial Capital, Social Capital and Life Satisfaction. British Journal of Social Psychology, 52(1), 25-43. doi:10.1111/j.2044-8309.2011.02035.x

Graham, C. (2010). Happiness around the World: The Paradox of Happy Peasants and Miserable Millionaires. Oxford: Oxford University Press.

Greve, B. (2012). The Impact of the Financial Crisis on Happiness in Affluent European Countries. Journal of Comparative Social Welfare, 28(3), 183-193. doi:10.1080/17486831.2012.736354

Gundlach, E., \& Opfinger, M. (2013). Religiosity as a Determinant of Happiness. Review of Development Economics, 17(3), 523-539. doi:10.1111/rode. 12047

Guven, C., \& Sørensen, B. (2012). Subjective Well-Being: Keeping up with the Perception of the Joneses. Social Indicators Research, 109(3), 439-469. doi:10.1007/s11205-011-9910-x

Hayborn, D. M. (2008). The Pursuit of Unhappiness . Oxford, UK: Oxford University Press.

Headey, B., Muffels, R., \& Wooden, M. (2008). Money Does not Buy Happiness: Or Does It? A Reassessment Based on the Combined Effects of Wealth, Income and Consumption. Social Indicators Research, 87(1), 65-82. doi:10.1007/s11205-007-9146-y

Kuroki, M. (2013). Crime Victimization and Subjective Well-Being: Evidence from Happiness Data. Journal of Happiness Studies, 14(3), 783-794. doi:10.1007/s10902-012-9355-1

Liberman, V., Boehm, J. K., Lyubomirsky, S., \& Ross, L. (2009). Happiness and Memory: Affective Significance of Endowment and Contrast. Emotion, 9, 666-680.

Lyubomirsky, S. (2001). Why are some People Happier than Others?: The Role of Cognitive and Motivational Processes in Well-being. American Psychologist, 56, 239-249.

Lyubomirsky, S., \& Kasri, F. (2006). Levels of Private Self-consciousness and Mood Awareness among Happy and Unhappy Individuals. Unpublished raw data.

Lyubomirsky, S., \& Tucker, K. L. (1998). Implications of Individual Differences in Subjective Happiness for Perceiving, Interpreting, and Thinking about Life Events. Motivation and Emotion, 22, 155-186.

Lyubomirsky, S., King, L., \& Diener, E. (2005). The Benefits of Frequent Positive Affect: Does Happiness lead to Success? Psychological Bulletin, 131, 803-855.

Lyubomirsky, S., Tkach, C., \& DiMatteo, M. R. (2006). What are the Differences between Happiness and Self-esteem? Social Indicators Research, 78, 363-404.

Oshio, T., \& Kobayashi, M. (2011). Area-Level Income Inequality and Individual Happiness: Evidence from Japan. Journal of Happiness Studies, 12(4), 633-649. doi:10.1007/s10902-010-9220-z

Oshio, T., Nozaki, K., \& Kobayashi, M. (2011). Relative Income and Happiness in Asia: Evidence from Nationwide Surveys in China, Japan, and Korea. Social Indicators Research, 104(3), 351-367. doi:10.1007/s11205-010-9754-9

Parducci, A. (1995). Happiness, Pleasure, and Judgment: The Contextual Theory and Its Applications. Mahwah, NJ: Lawrence Erlbaum Associates.

Powdthavee, N. (2010). How much does Money Really Matter? Estimating the Causal Effects of Income on Happiness. Empirical Economics, 39(1), 77-92. doi:10.1007/s00181-009-0295-5

Roszkowski, M. J., \& Grable, J. (2007). How Are Income and Net Worth Related to Happiness? Journal of Financial Service Professionals, 61(1), 64-80.

Rözer, J., \& Kraaykamp, G. (2013). Income Inequality and Subjective Well-being: A Cross-National Study on the Conditional Effects of Individual and National Characteristics. Social Indicators Research, 113(3), 1009-1023. doi:10.1007/s11205-012-0124-7

Ryan, R. M., \& Deci, E. L. (2000). Self-Determination Theory and the Facilitation of Intrinsic Motivation, Social Development, and Wellbeing. American Psychologist, 55, 68-78.

Ryff, C. D., \& Singer, B. (1996). Psychological Well-being: Meaning, Measurement, and Implications for Psychotherapy Research. Psychotherapy and Psychosomatics, 65 , 14-23.

Schneider, L. (2013). A Note on Income Aspirations, Television and Happiness. Kyklos, 66(2), 301-305. doi:10.1111/kykl.12022

Schwarze, J., \& Winkelmann, R. (2011). Happiness and Altruism within the Extended Family. Journal of Population Economics, 24(3), 1033-1051. doi:10.1007/s00148-010-0326-8

Seligman, Martin. (2011). Flourish: A Visionary New Understanding of Happiness and Well-being. New York: Free Press.

Sirgy M. J. (2012). The Psychology of Quality of Life. Hedonic Well-Being, Life Satisfaction, and Eudaimonia. Springer Science+Business Media B.V. 2012.

Sirgy, M. J., \& Wu, J. (2009). The Pleasant Life, the Engaged Life, and the Meaningful Life: What about the Balanced Life? Journal of Happiness Studies, $10,183-196$.

Stevenson, B., \& Wolfers, J. (2008). Economic Growth and Subjective Well-Being: Reassessing the Easterlin Paradox. Brookings Papers On Economic Activity, (1), 1-87.

Tao, H., \& Chiu, S. (2009). The Effects of Relative Income and Absolute Income on Happiness. Review of Development Economics, 13(1), 164-174. doi:10.1111/j.1467-9361.2008.00492.x 


\section{The International Journal}

\section{ENTREPRENEURSHIP AND SUSTAINABILITY ISSUES}

ISSN 2345-0282 (online) http://jssidoi.org/jesi/ 2016 Volume 4 Number 2 (December)

Tov, W., \& Diener, E. (2009). The Well-being of Nations: Linking together Trust, Cooperation, and Democracy. In E. Diener (Ed.), The Science of Well-being: The Collected Works of Ed Diener (pp. 155-173). Dordrecht, the Netherlands: Springer.

Veenhoven, R. (2003). Hedonism and happiness. Journal of Happiness Studies, 4, 437-457.

Wang, M., \& Sunny Wong, M. C. (2011). Leisure and Happiness in the United States: Evidence from Survey Data. Applied Economics Letters, 18(18), 1813-1816. doi:10.1080/13504851.2011.564123

Warburton, D. (1996). The Functions of Pleasure. In D. Warburton \& N. Sherwood (Eds.), Pleasure and Quality of Life. Chichester, UK: Wiley.

Yalom, I. D. (1989). Love's Executioner, and Other Tales of Psychotherapy. New York, N.Y: Harper Perennial.

Zagórski, K. (2011). Income and Happiness in Time of Post-Communist Modernization. Social Indicators Research, 104(2), 331-349. doi:10.1007/s11205-010-9749-6

Zagórski, K., Kelley, J., \& Evans, M. R. (2010). Economic Development and Happiness: Evidence from 32 Nations. Polish Sociological Review, (169), 3-19.

Zhang, H., \& Tsang, S. (2013). Relative Income and Marital Happiness Among Urban Chinese Women: The Moderating Role of Personal Commitment. Journal of Happiness Studies, 14(5), 1575-1584. doi:10.1007/s10902-012-9396-5

Zuzanek, J. (2013). Does Being Well-Off Make Us Happier? Problems of Measurement. Journal of Happiness Studies, 14(3), 795-815. doi:10.1007/s10902-012-9356-0

\section{Aknowledgements}

This work was supported by the Research Council of Lithuania [grant number GER-009/2015].

Aiste DIRŽYTÉ - researcher, clinical psychologist, Head of Psychological Well Being Research Laboratory at MRU, Professor at Institute of Psychology, MRU and Assoc. Prof. at at Business School at Vilnius University (since 2013). She holds a PhD in psychology (since 2001). She is also a founder of the Institute of Management and Psychology (2008), Life Quality Improvement Center (2002), and participates in Melkys' ecocommunity (since 2012). Aiste Dirzyte is a member of American Psychological Association and International Positive Psychology Association. Research interests: NVC (non violent communication), PsyCap (psychological capital: self efficacy, hope, resilience, optimism), POB (positive organizational behavior), positive leadership, self management (self regulation, self acceptance, self compassion).

Ona Gražina RAKAUSKIENE - Dr. Habil. of Social Sciences (Economics), Professor of Mykolas Romeris University, Head of the Quality of Life Laboratory. Research interests: quality of life, sustainable wellbeing, gender economics, social and economic cohesion policy of EU. Ona Grazina Rakauskiene - is a researcher, an expert and leader of researches and projects. During her scientific career, she has built up significant experience in research projects' management at the national and international levels. She has prepared abosues ut 300 scientific publications, 10 monographs, participated in more than 50 projects and scientific applied researches as a research leader. She was an Expert of the International Consulting Group OXFORD XXI (Great Britain, London) according to the programme EC FP7 ENRI - East (2011-2013), member of the organisational committee of the International Network "Nord-Baltic Gender Responsive Budget" (2007-2011), Editor-in-Chief and Chairwoman of editorial board of scientific research journal of Mykolas Romeris University "Intelectual Economics" (2011- 2015), now she is member of editorial boards of scientific research journals of Mykolas Romeris University "Intelectual Economics” (Lithuania), of University „Torun School of Banking“ „, Torun Business Review“, of international scientific research journal „Journal of Security and Sustainability Issues” (SCOPUS), Elsevier; of international scientific research journal „Entrepreneurship and Sustainability Issues” (Thomson Reuters, Scopus). 2014-2016 Member of editorial board of international scientific research journal „Entrepreneurship and Sustainability Issues”, ISSN 2345-0282 online, SCOPUS, Thomson Reuters, http://jssidoi.org/jesi/aims

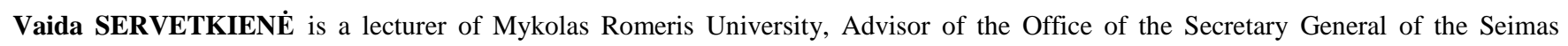
(Parliament) of the Republic of Lithuania. She has an experience both in the field of scientific research and in the field of public administration. Therefore in the Project's implementation there will be useful to connect the results of scientific research with their practical application. In 2013 V. Servetkienè defended doctoral dissertation "Multidimensional Assessment of the Quality of Life Identifying Critical Areas" (Social Sciences, Economics). Scientific research interests: quality of life of population, material welfare, socioeconomic inequality, social exclusion and vulnerable society groups. V. Servetkienè has published 13 scientific publications, together with co-authors has published 4 monographs, and 1 scientific study

Copyright (C) 2016 by author(s) and VsI Entrepreneurship and Sustainability Center

This work is licensed under the Creative Commons Attribution International License (CC BY).

http://creativecommons.org/licenses/by/4.0/

cC) (i) Open Access 